\title{
Endoscopic Ultrasound-Guided Sampling for Personalized Pancreatic Cancer Treatment
}

\author{
Eisuke Iwasaki ${ }^{1, *(D)}$, Seiichiro Fukuhara ${ }^{2}$, Masayasu Horibe ${ }^{1}$, Shintaro Kawasaki ${ }^{1}$, Takashi Seino ${ }^{1}$, \\ Yoichi Takimoto ${ }^{1}$, Hiroki Tamagawa ${ }^{1}$, Yujiro Machida ${ }^{1}$, Atsuto Kayashima ${ }^{1}$, Marin Noda ${ }^{1}$, Hideyuki Hayashi ${ }^{3}$ D \\ and Takanori Kanai ${ }^{1}$
}

1 Division of Gastroenterology and Hepatology, Department of Internal Medicine, Keio University School of Medicine 35, Shinanomachi, Shinjuku-ku, Tokyo 160-8582, Japan; masayasu.horibe@gmail.com (M.H.); s.kawasaki@keio.jp (S.K.); seinosann@gmail.com (T.S.); takimoto.yo1@gmail.com (Y.T.); h.tamagawa@keio.jp (H.T.); machiyumachiyu@keio.jp (Y.M.); shimauma@keio.jp (A.K.); jesuis_intense@yahoo.co.jp (M.N.); takagast@keio.jp (T.K.)

2 Center for Diagnostic and Therapeutic Endoscopy, Keio University School of Medicine 35, Shinanomachi, Shinjuku-ku, Tokyo 160-8582, Japan; fukuharas@keio.jp

3 Keio Cancer Center, Genomic Units, Keio University School of Medicine 35, Shinanomachi, Shinjuku-ku, Tokyo 160-8582, Japan; rock-hayashi-pop@keio.jp

* Correspondence: e-iwa@keio.jp; Tel.: +81-91-4542-3078

check for updates

Citation: Iwasaki, E.; Fukuhara, S.; Horibe, M.; Kawasaki, S.; Seino, T.; Takimoto, Y.; Tamagawa, H.; Machida, Y.; Kayashima, A.; Noda, M.; et al. Endoscopic Ultrasound-Guided Sampling for Personalized Pancreatic Cancer Treatment. Diagnostics 2021, 11, 469. https://doi.org/10.3390/ diagnostics11030469

Academic Editor: Christian Jenssen

Received: 26 January 2021

Accepted: 27 February 2021

Published: 8 March 2021

Publisher's Note: MDPI stays neutral with regard to jurisdictional claims in published maps and institutional affiliations.

Copyright: (c) 2021 by the authors. Licensee MDPI, Basel, Switzerland. This article is an open access article distributed under the terms and conditions of the Creative Commons Attribution (CC BY) license (https:// creativecommons.org/licenses/by/ $4.0 /)$.

\begin{abstract}
Pancreatic cancer is the most lethal solid malignancy, and the number of patients with pancreatic cancer is increasing. Systemic chemotherapies are often ineffective for such patients, and there is an urgent need for personalized medicine. Unlike other types of cancer, personalized treatments for pancreatic cancer are still in development. Consequently, pancreatic cancer is less sensitive to anticancer drugs and is often refractory to common treatments. Therefore, advances in personalized medicine for pancreatic cancer are necessary. This review examined advances in personalized medicine for pancreatic cancer, including the use of endoscopic ultrasound (EUS)guided sampling. EUS-guided sampling is widely used for diagnosing pancreatic tumors and is expected to be applied to sampled tissues. Additionally, there has been an increase in clinical research using EUS-guided sampling. The combination of precision medicine using genomic testing and pharmacological profiles based on high-throughput drug sensitivity testing using patient-derived organoids is expected to revolutionize pancreatic cancer treatment.
\end{abstract}

Keywords: EUS-guided sampling; pancreatic cancer; patient-derived organoid; precision medicine

\section{Introduction}

The number of patients diagnosed with pancreatic duct tumors is increasing annually. Currently, pancreatic ductal adenocarcinoma (PDAC) is the seventh leading cause of cancer death worldwide, with an estimated 432,000 new cases and 459,000 deaths yearly [1]. Pancreatic malignancies are difficult to detect at an early stage; patients are often diagnosed in advanced stages, and many patients receive chemotherapy [2]. However, patients with pancreatic malignancy have a five-year survival rate of less than $10 \%$, even when treated [3]. These tumors have been classified as the most intractable malignant tumors with low antineoplastic sensitivity, and the development of innovative diagnostic techniques and treatments is required.

Since chemotherapy is administered uniformly based on the results of clinical trials, therapeutic effects vary from patient to patient. This may be because the efficacies of anticancer drugs differ due to genomic differences, even in patients with the same cancer [4]. Therefore, there is a limit on improving clinical results of anticancer drugs for advanced PDAC, and there is a need for personalized treatments for patients with PDAC.

Endoscopic ultrasound (EUS)-guided sampling, which can reliably collect tissue from malignant tumors of the bile duct and pancreas before administering chemotherapy, has 
been developed to facilitate the tissue collection of malignant tumors since the 1990s [5]. With the development of needles and the availability of EUS worldwide, EUS-guided sampling has been used in actual clinical settings. EUS-guided sampling has the potential to advance personalized treatment by allowing the assessment of genomic alterations and drug sensitivity [6-8].

Neoadjuvant chemotherapy has been common for operable or borderline PDAC [9]. In the future, the need for EUS-guided sampling will increase as the number of upfront resections for early PDACs without pathological confirmation decreases. EUS-guided sampling allows the collection of tissue aspirations by inserting a thin needle into the lesion using real-time endoscopic ultrasonography. Initially, various immunohistochemical biomarkers and RAS gene mutations were used as diagnostic aids. However, in addition to classical tissue hematoxylin-eosin staining and Papanicolaou staining, other diagnostic methods using EUS-guided samples have made remarkable progress $[8,10,11]$. The utility of sensitivity testing using 2D-cultured cancer cells of individual patients with PDAC has been examined, however this method was found to have poor clinical utility due to poor establishment efficiency [12].

Next-generation sequencing (NGS) that collectively captures cellular activities using conventional methods, such as polymerase chain reaction, Western blotting, and enzymelinked immunosorbent assays that examine a single gene or protein have been proposed for analyzing tumor tissue [13]. The invention of organoid technology, which enables cancer and normal cell culture biopsies with high efficiency and greatly influences modern biological research, has led to great advances in medical technology. High-throughput methods have also been developed for drug sensitivity testing, and technological innovations are occurring rapidly. By applying these technologies, various studies using cancer tissues are currently being actively conducted [14-16].

Here, we summarize recent studies on personalized medicine for PDAC and show recent findings regarding the application of EUS-guided sampling to personalized medicine.

\section{Personalized Cancer Treatment Using Genomic Profiling}

\subsection{The Current Status of Cancer Precision Medicine}

Traditional anticancer drugs act on all rapidly dividing normal cells and cancer cells. Therefore, the approach to treatment is shifting to genetically modified strategies that identify potential therapeutic targets with enhanced specificity. However, it is necessary to conduct genotype-matched clinical trials, such as basket and umbrella studies, to confirm the usefulness of cancer precision medicine [17,18]. Several large basket trials aimed at studying different cancer types, such as the Targeted Agent and Profiling Registry, are currently underway and are expected to provide genotype-matched treatment strategies [19-23].

Genomic sequencing assays for tumor analysis are a recent development in the field of cancer treatment $[13,24]$. The increased worldwide availability of NGS in recent years has facilitated the analysis of genomic biomarkers. Precision medicine based on genomic biomarkers is perhaps most frequently used to treat lung adenocarcinoma [25]. Genomic tests for EGFR mutations [26], ALK fusions [27], ROS1 fusions [28], and BRAF mutations are widely used as clinical tests, and corresponding molecular-targeted therapies have become the standard treatment for patients with lung cancer. Moreover, high microsatellite instability and mismatch repair deficiency have been utilized as biomarkers for programmed cell death 1 inhibitors, and NTRK fusions have been utilized as tumor-agnostic genomic biomarkers for TRK inhibitors [29].

In a recent large cohort study of 10,000 cancer patients using the MSK-IMPACT platform, 37\% of patients had actionable genetic changes. However, since then, only $11 \%$ have been enrolled in genotype-matched clinical trials [30]. Conversely, treatment with molecularly matched therapies has been reported to significantly improve survival outcomes in patients with pancreatic cancer, based on the ongoing Know Your Tumor program, including 1000 patients with PDAC [4]. 


\subsection{Using EUS-Guided Sampling to Improve Personalized Treatment for PDAC}

There are some unresolved issues regarding genomic testing for PDAC in clinical practice. It is often possible to obtain sufficient surgical specimens and biopsy samples for other tumors, however the difficulty in obtaining pancreatic tumor samples is a major problem. EUS-guided sampling has been used to collect tumor samples from the pancreas since the 1990s and has become widely used as the first choice for sampling PDACs [31].

EUS-guided fine-needle aspiration (FNA) was first described in 1993 by Vilmann et al. as a technique to collect samples for smear cytology [32]. Later, this technique was also used to obtain material for histological and immunohistochemical samples, as well as for molecular processing (cell block technique, tissue core acquisition). In some studies, $>80 \%$ of EUS-FNA samples were adequate for histology and immunohistochemistry [33-35]. In the early years of this century, a new approach to EUS-guided sampling was initiated: to yield intact tissue cores with specifically designed needles called EUS fine-needle biopsy (FNB). The first generation of these core needles was based on the trucut biopsy technique (QuickCore, Wilson-Cook, Winstom Salem, NC, USA) [36], but results were limited by technical problems. Second generation needles with side-hole bevels (ProCore, Wilson-Cook) [37] and third generation needles with Franseen-type bevels (Acquire, Boston Scientific, Marlborough, MA, USA) [38] or fork-tip type bevels (SharkCore, Medtronic, Minneapolis, MN, USA) [39] proved to be more effective in terms of larger amounts of cohesive tissue with preserved tissue architecture and fewer needle passes needed to obtain samples adequate for diagnosis. Furthermore, the large amount of core tissue obtained from PDACs provides an opportunity for immunostaining, histologic diagnosis, and molecular and genetic analyses for personalized treatment.

Currently available cancer genomic profiling tests, such as the FoundationOne CDx (Foundation Medicine, Cambridge, MA, USA), which is a qualitative NGS-based in vitro diagnostic test that uses high-throughput hybridization-based capture technology to detect large amounts of genomic information, usually requiring 10-500 ng of DNA. However, it is still unclear whether EUS-guided sampling is the optimal method for collecting tumor samples for genomic sequencing of PDACs $[10,11,40]$. For genomic analysis, the collected sample is fixed with formalin and laser capture microdissection is performed to extract DNA. Archival samples, like formalin-fixed paraffin-embedded tissue obtained from EUSguided sampling, are often unusable due to problems such as low quantity or quality of tissue and reduced-quality DNA $[7,11]$. It is necessary to identify a method of collecting samples for genomic testing and diagnosis rather than using archived samples.

Successful molecular biological analysis from fixed formalin specimens of cell specimens collected by EUS-FNA was reported in 2010 by Fujita et al. [41]. In 2012, Bournet et al. extracted RNA directly from samples collected by EUS-FNA and EUS-FNB for molecular subtyping of PDACs [11]. In addition, the first attempt to evaluate the chemotherapysensitivity to PDACs using RNA extracted from EUS-FNA was reported in 2010 by a Japanese group [42]. It has been reported that greater DNA yield can be collected by freezing the collected sample and extracting the DNA [6]; this is expected to be applied in the future. Due to low DNA quality, additional tissue sampling is often required in the clinic. Published studies with two novel needles, Franseen and fork-tip needles, demonstrated a significant difference in terms of sample adequacy, accuracy, or acquisition of histologic materials when compatible with standard EUS-guided sampling [43]. Additionally, a randomized study demonstrated higher histologic yield, tumor cellularity, and surface using EUS-FNB needles [44]. Several studies have reported a higher success rate of NGS using EUS-guided samples (Table 1). Larson et al. reported an NGS success rate of $70.4 \%$ using EUS-FNB, compared to only $42.9 \%$ when using EUS-FNA. Elhanafi et al. reported that the success rate of NGS using FNB samples was 90.9\%, much higher than the $66.9 \%$ that was achieved when using FNA [10]. Therefore, we recommend the FNB needle to collect DNA for genomic testing. On the other hand, some studies, including pharmacological profiling, have shown that "real-world" EUS-FNA samples can be used for genome profiling using NGS $[6,8]$. A recent study showed no superiority of EUS-FNB over EUS-FNA for RNA 
extraction from PDACs [45]. Therefore, further research is needed to determine which sampling (type of puncture needle, gauge, amount of tissue to be collected, suction method, etc.) and specimen processing methods are suitable for obtaining good-quality RNA and DNA samples [40].

Table 1. Precision medicine for pancreatic ductal adenocarcinoma (PDAC) using endoscopic ultrasound (EUS)-guided sampling.

\begin{tabular}{|c|c|c|c|}
\hline Authors and Year & $\begin{array}{l}\text { Method of Sampling and Type } \\
\text { of Needle }\end{array}$ & Number of Patients & $\begin{array}{c}\text { Successfully Sequenced } \\
\text { Samples, n (\%) }\end{array}$ \\
\hline \multirow{3}{*}{ Larson et al. [10], 2018} & EUS-FNB & 54 & $38(70.4 \%)$ \\
\hline & EUS-FNA & 7 & $3(42.9 \%)$ \\
\hline & Percutaneous & 8 & $8(100 \%)$ \\
\hline Hayashi et al. [40], 2018 & EUS-FNA (FFPE) 22-G & 9 & $\begin{array}{c}7(78 \%) \\
\text { Re-hions }\end{array}$ \\
\hline \multirow{2}{*}{ Elhanafi et al. [46], 2020} & EUS-FNB 22-G & 22 & $\begin{array}{c}\text { Re-biopsy } 2(22 \%) \\
20(90.9 \%)\end{array}$ \\
\hline & EUS-FNA 22-G & 145 & $97(66.9 \%)$ \\
\hline Semaan et al. [47], 2020 & EUS-FNA (cytology) & ND & $23(\mathrm{ND})$ \\
\hline Kandel et al. [6], 2020 & $\begin{array}{l}\text { EUS-FNB (fresh frozen) } \\
\text { EUS-FNA (fresh frozen) } \\
\text { 19-G for body and tail/22-G for head }\end{array}$ & $\begin{array}{l}50 \\
50\end{array}$ & $\begin{array}{l}39(78 \%) \\
7(14 \%)\end{array}$ \\
\hline
\end{tabular}

EUS-FNA: endoscopic ultrasound-guided fine-needle aspiration, EUS-FNB: endoscopic ultrasound-guided fine-needle biopsy, FFPE: formalin-fixed paraffin-embedded, ND: not determined: PDAC, pancreatic ductal adenocarcinoma.

\subsection{Cancer Genomic Medicine for PDAC: A Future Perspective}

PDAC has been reported to have only a few druggable gene alterations. Two large cohort studies have investigated the status of PDAC mutations using genomic analysis. Although KRAS, CDKN2A, TP53, and SMAD4 have been identified as the major driver genes for PDAC, detection rates for other genetic alterations have been reported to be very low [48-50]. A retrospective study examined 336 PDAC patients who underwent genomic sequencing to identify gene mutations. Only $1 \%$ of these patients reported receiving consistent treatment based on sequencing results. From these results, the authors concluded that the practical application of precision medicine for PDAC is currently limited [51].

Precision medicine for PDAC is currently still under development. For example, targeting genetic alterations associated with homologous recombination deficiencies such as $B R C A 1 / 2, P A L B 2, F A N C$, and $A T M$ has been reported to be a promising therapeutic strategy for PDACs that are sensitive to poly (ADP-ribose) polymerase (PARP) inhibitors and platinum [49]. The PARP inhibitor Olaparib was recently approved to be used in maintenance therapy after platinum-based treatment in PDAC cases with germline BRCA mutations [52]. The further development of a comprehensive gene panel containing genes specific to PDAC and associated with predictive biomarkers for DNA damage repair and immunotherapy is expected.

\section{Personalized Cancer Treatment Using Pharmacological Profiling}

\subsection{Effectiveness and Role of Chemosensitivity Tests for PDAC Treatment}

Although gene mutations promote tumor progression, some reports have suggested that they may be less associated with chemotherapy resistance [53-55]. One study found that global genomic features cannot classify tumors or predict therapeutic responses [53]. Similar results were found in another report of a larger cohort of patients using the wholegenome sequencing approach [54]. Sensitivity studies to numerous drugs have been reported in 28 PDAC patient-derived cell lines and xenografts; however, there was a correlation between therapeutic efficacy and gene mutation in only one case [55]. These data highlight the risk of relying on genetic analyses alone to predict the efficacy of currently available drugs for PDAC. Alternatively, sensitivity profiling that assesses cell viability by administering therapeutic agents to the patient's cancer-derived tissue has been suggested 
to provide useful information for personalized PDAC treatment. However, attempts to assess drug sensitivity using patient-derived "cell lines", have not been successful.

Precision medicine approaches for PDAC are challenging because of the short median survival of patients with metastatic PDAC. Furthermore, sensitivity testing is difficult for the following reasons: (1) difficulty in establishing cell culture [12]; (2) the long time required to get results [56]; (3) sequential tumor chemosensitivity changes due to treatment with chemotherapy [57]; and (4) individual tumor heterogeneity [58]. To effectively assess chemosensitivity for PDAC, it is necessary to have good access to repeated tissue samplings at multiple sites, depending on the patient's clinical course, and obtain a high culture success rate and more rapid test results. Therefore, technology that overcomes these difficulties is necessary.

\subsection{Patient-Derived Tumor Organoids for PDAC: A Future Perspective}

To evaluate the drug sensitivity of pancreatic malignancies, it is necessary to establish a more efficient method for culturing cancer cells. The cancer stem cell hypothesis states that there is a small subpopulation of cells in tumors with a capability of self-renewal and tumorigenicity. However, attempts to culture those cancer stem cells have been unsuccessful. In 2007, it was reported that colon cancer stem cells could be cultured using the sphere culture method [59], but the success rate was low (20-30\%), which is not practical for clinical use. The organoid culture system, developed by Sato et al. in 2009, made it possible to expand normal and cancer adult cells. Organoids are thought to be selforganized from single stem cells, which phenotypically and molecularly mimic the origin of tissues and organs. This technology is a powerful tool because it can be applied NGS and genomic modification using CRISPR-Cas9 technology. The applications of organoids have advanced to evaluate gastrointestinal membrane permeability in two-dimensional cultures [60]. Additionally, the success rate of PDAC organoid establishment is much higher than that of primary cell cultures [61]. Furthermore, high-throughput methods to examine drug sensitivity in organoids have been developed, requiring only six weeks to complete [62]. If an effective drug can be identified more quickly, it may be possible to select the appropriate treatment for initial chemotherapy.

Patient-derived organoids (PDOs) have the potential to be used as important tools for personalized cancer treatment [63]. Basic cancer research using PDOs was first reported in our institution $[61,64,65]$. Many studies have reported that PDOs are good models for drug screening and predicting the response to treatments $[14,62,66]$. Additionally, pharmaceutical profiling through EUS-guided sampling and PDOs is likely to be useful for improving PDAC treatment, targeting vulnerabilities of tumors in individual patients. EUS-guided sampling can be repeatedly performed with low risk of complications, making it possible to obtain samples from liver metastases and ascites as well as the primary lesion [66].

Whether the clinical implementation of PDOs for drug sensitivity tests is useful has not been fully evaluated for PDAC. However, irradiation/drug tests using rectal cancer PDOs were reported to have an accuracy of $84.4 \%$ in the clinical treatment course. In most rectal cancer cases, PDO response analysis was completed in less than four weeks, enabling treatment recommendations to be generated within a clinically meaningful time frame [67]. If these results can be applied to PDAC cases, they are expected to be very useful for personalized medicine.

\subsection{EUS-Guided Sampling for Personalized Medicine Using PDOs}

Only $\sim 20 \%$ of patients with PDAC are eligible for surgical intervention [68], and sufficient tissue could be available, making it easy to diagnose and culture PDOs. By applying EUS-guided sampling to inoperable patients, it has become possible to overcome the limitations of taking samples from PDAC tumors and obtain the necessary tissue. PDOs can be cultured by collecting a small amount of tissue separately from the pathological diagnostic sample, which does not interfere with clinical examination in the actual clinical 
setting. EUS-guided sampling can also be safely performed in patients at any stage of PDAC as well as preoperatively, before and after radiation and chemotherapy, and after recurrence.

Recently, there have been increasing numbers of reports on how to effectively collect specimens to establish organoids (Table 2). FNB-based tissue sampling has become more common than FNA-based cytology for diagnosing PDAC. Many studies have suggested the usefulness of 22-gauge FNB needles for PDAC diagnosis [69] because this size of FNB needle allows for core tissue samples with fewer passes. Aspiration of core tissue with preserved architecture is also beneficial for diagnosis and obtaining a sufficient amount of sample for the organoid establishment and molecular genetic studies. The success rate of PDO establishment from tissues obtained through EUS-guided sampling is reported to be about $60 \%$ to $82 \%$ [61,62,70-74], which is the same success rate as with surgically resected tissues. Furthermore, there is no significant difference in the establishment efficiency between single-pass and double-pass punctures, therefore single-pass punctures with a 22-gauge FNB needle are recommended [74]. However, there are still only a few reports regarding the method of EUS-guided sampling for PDO establishment; therefore, further research is needed.

Table 2. Culture of patient-derived organoids.

\begin{tabular}{cccc}
\hline Authors, Year & Method of Sampling/Type of Needle & Number of Patients & $\begin{array}{c}\text { Number of Organoids } \\
\text { Created n (\%) }\end{array}$ \\
\hline Boj et al. [70], 2015 & FNA/ND & ND & 2 (primary and metastasis) \\
Tiriac et al. [62], 2018 & FNB/22-G & 60 & $43(71 \%)$ \\
Seino et al. [61], 2019 & FNB/22-G & ND & $27(\mathrm{ND})$ \\
Bian et al. [71], 2019 & FNB/ND & ND & $24(85 \%)$ \\
Henning et al. [75] 2019 & FNA/ND & 6 & $5(83 \%)$ \\
Vilgelm et al. [72], 2020 & FNA/25-G & 5 & $5($ ex vivo tumor, 100\%) \\
Juiz et al. [73], 2020 & ND & ND & $20($ ND) \\
Lacomb et al. [74], 2020 & FNB/22-G 1 pass & 25 & $22(88 \%)$ \\
\hline
\end{tabular}

EUS-FNA: endoscopic ultrasound-guided fine-needle aspiration, EUS-FNB: endoscopic ultrasound-guided fine-needle biopsy, ND: not determined.

\subsection{Human PDOs Establishment from EUS-Guided Sampling}

Methods for establishing PDAC organoids have been reported by multiple research groups. In the field of PDAC-related organoid research, the first organoid was generated from mouse pancreatic tissues [63,64]. Following this, the creation of organoids derived from human PDAC has been achieved via various methods. Some groups embed cells in Matrigel overlaid with culture medium, while others culture cells on a Matrigel bed covered with a mixture of Matrigel and culture medium. Matrigel serves as the scaffold for epithelial cells because it includes multiple extracellular matrix proteins, some of which are members of the basal membrane.

There have also been several reports on how to generate PDOs from PDAC specimens collected by EUS-guided sampling. The Tuveson research group [62,63], which has created the largest PDAC organoid library, has reported a detailed method for PDO establishment from the small amount of needle biopsy samples. Tiriac et al. described the method as follows [8]. Tissue samples collected by EUS-guided sampling were usually contaminated with numerous red blood cells due to sample aspiration during the procedure; therefore, the specimens needed to be treated with blood cell lysis to remove them and then mechanically dissociated in digestion media. These tissue fragments were then plated with dome-type Matrigel and overlaid with a culture medium. The addition of niche factors (EGF, FGF10, BMP inhibitor, TGF-beta receptor inhibitor, Wnt3A, and Rspondin1) to the culture medium to maintain the stemness of the PDOs was an essential process for organoid culture. Seino et al. described that the obtained specimens were chemically dissociated into single cells 
before embedment in Matrigel [56]. Subsequently, the Matrigel dome was overlaid with a basal culture medium, supplemented with niche factors required for each PDO growth (Table 3).

Table 3. Methods to culture organoids from human PDAC using EUS-guided sampling.

\begin{tabular}{|c|c|c|}
\hline Authors, Year & ECM-Matrix & Medium \\
\hline Tiriac et al., 2018 [8] & $\begin{array}{l}\text { Matrigel 100\% } \\
\text { Dome-type }\end{array}$ & $\begin{array}{l}\text { Advanced DMEM/F12, HEPES (10 mM), Glutamax (1X), A83-01 (500 nM), } \\
\text { hEGF (50 ng/mL), mNoggin (100 ng/mL), hFGF10 (100 ng/mL), hGastrin I } \\
(10 \mathrm{nM}), \text { N-acetylcysteine }(1.25 \mathrm{mM}) \text {, Nicotinamide }(10 \mathrm{mM}), \text { PGE2 }(1 \mu \mathrm{M}) \text {, } \\
\text { B27 supplement (1X), R-spondin-1 (10\%), Afamin/Wnt3A (50\%). }\end{array}$ \\
\hline Seino et al., 2018 [61] & $\begin{array}{l}\text { GFR-Matrigel 100\% } \\
\text { Dome-type }\end{array}$ & 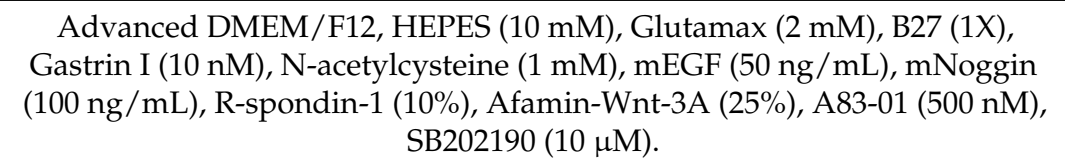 \\
\hline $\begin{array}{c}\text { Bian et al., } 2019 \\
\text { [71]/Juiz et al., } 2020 \text { [73] }\end{array}$ & $\begin{array}{l}\text { GFR-Matrigel 100\% } \\
\text { Dome-type }\end{array}$ & $\begin{array}{l}\text { Advanced DMEM/F12, HEPES (10 mM), Glutamax (1X), hFGF10 (100 } \\
\text { ng/mL); hEGF (50 ng/mL), hNoggin (100 ng/mL), Wnt3a (30\%), } \\
\text { R-spondin-1 (10\%), hGastrin I (10 nM), Nicotinamide }(10 \mathrm{mM}), \\
\text { N-acetylcysteine (1.25 mM), B27 (1X); A83-01 (500 nM); Y27632 (10.5 } \mu \mathrm{M}) .\end{array}$ \\
\hline Hennig et al., 2019 [75] & $\begin{array}{l}\text { GFR-Matrigel } \\
\text { Dome-type }\end{array}$ & 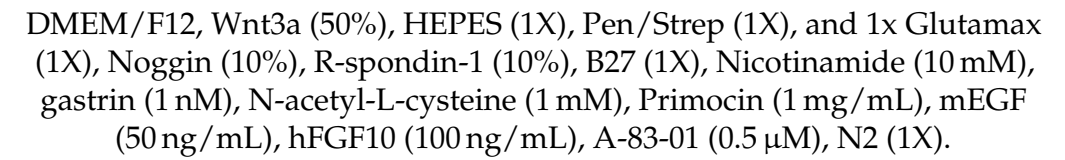 \\
\hline
\end{tabular}

DMEM: Dulbecco's modified Eagle's medium; EGF, epidermal growth factor; FGF, fetal growth factor; GFR, growth factor reduced; PDAC, pancreatic ductal adenocarcinoma.

The niche factors, which are essential for the growth and survival of PDOs are determined by each organoid culture. Normal human pancreas-derived organoids require EGF, BMP inhibitor, TGF-beta receptor inhibitor, Wnt3A, and Rspondin1, while some PDAC organoids can still propagate without some of these factors due to genetic aberrations. Despite the lack of genetic abnormalities in canonical Wnt signaling pathways, comportment of the PDAC organoids could still expand in Wnt or R-spondin free environments. Seino et al. proposed the classification of PDACs based on Wnt signaling dependency and revealed that PDACs could potentially become more malignant, with independence from the stem cell niche. Our understanding of the minimum culture condition in which some of the niche factors are depleted enables us to predict the existence of genetic changes and the malignant status of original tumors.

\subsection{High Throughput Drug Screening Test Using PDOs}

First, we will discuss the high-throughput method, which has rapidly promoted the practical application of actual drug screening testing. High-throughput screening (HTS) is now being used for basic and applied research in academia [15]. It comprises the screening of large chemical libraries for activity against biological targets via the use of miniaturized assays and large-scale data analysis. A high-throughput analysis is performed using 96-, 384-, or 1536-well microtiter plates. Generally, organoid cells are embedded in a Matrigel-coated plate and cultured using a culture medium containing niche factors. After administering a serially diluted solution of each drug to the well, drug screening is performed by assaying the cell death of organoids. The luminescence ATP-based assay (CellTiter-Glo ${ }^{\circledR}$ 3D cell viability assay, Promega) is reported to be used to determine the number of viable cells in 3D cell culture based on quantitation of the ATP present, a marker for the presence of active cells. Furthermore, an ATP-independent assay method to measure the activity of dead-cell protease, which is released from cells that have lost membrane integrity (CytoTox-Glo ${ }^{\mathrm{TM}}$ Cytotoxicity and CyQUANT ${ }^{\mathrm{TM}}$ assays, Promega), was also used in several reports. The CytoTox-Glo ${ }^{\mathrm{TM}}$ assay relies on the properties of recombinant luciferase, which uses aminoluciferin as a substrate to generate a stable luminescent signal. 
In principle, organoids are suitable for HTS, but the technical constraints and extensive manipulation required by current methods have hampered progress toward simple clinical applications. Therefore, various simple methods have been developed, and methods for reducing costs have been reported. Fluorometric methods to quantitatively assess cell death using propidium iodide and Hoechst fluorescence in 3D in a plate reader have been reported to have significantly improved analysis time, as well as ease of use, compared to other established methods [76]. Another cell death assay method, the bright-field method, uses a simplified geometry by seeding cells around the rim of the wells (mini-rings) [15]. This method has shown that organoids can be assayed on the same seeded plate, require fewer cells, and can be easily automated for HTS.

The proper timing for assaying cell death after drug administration remains unknown. Most reports have examined cell death approximately 1-5 days after drug administration. There has been not standardized method for HTS using PDOs, but it is expected that a consensus will soon be reached. There have been few actual reports on PDAC cases (Table 4), and further technological innovation is required for practical use.

Table 4. Methods of high-throughput drug screens for patient-derived organoids (PDOs) of PDAC.

\begin{tabular}{|c|c|c|c|c|c|c|}
\hline Authors, Year & Plate & $\begin{array}{l}\text { Number of } \\
\text { Seeded Cells }\end{array}$ & $\begin{array}{l}\text { Timing of } \\
\text { Assay }\end{array}$ & Assay Method & Target Agents & No of PDOs \\
\hline $\begin{array}{l}\text { Tiriac et al., } \\
2018 \text { [8] }\end{array}$ & 96 well & 500 cells/well & $\begin{array}{c}5 \text { days after } \\
\text { administration. }\end{array}$ & $\begin{array}{c}\text { CellTiter-Glo }^{\circledR} \\
\text { (luminescence ATP) }\end{array}$ & 5 & 66 \\
\hline $\begin{array}{l}\text { Driehuis et al., } \\
2019 \text { [56] }\end{array}$ & 384 well & ND & $\begin{array}{c}3 \text { days after } \\
\text { administration. }\end{array}$ & $\begin{array}{c}\text { CellTiter-Glo } \\
{ }^{\circledR} \\
\text { (luminescence ATP) }\end{array}$ & 76 & 24 \\
\hline $\begin{array}{l}\text { Frappart et al., } \\
\quad 2020[77]\end{array}$ & 96 well & 2000 cells/well & $\begin{array}{c}4 \text { days after } \\
\text { administration. }\end{array}$ & $\begin{array}{c}\text { CytoTox-Glo } \\
\text { (luminescence non-ATP) }\end{array}$ & 22 & 21 \\
\hline
\end{tabular}

ND, not determined; PDAC, pancreatic ductal adenocarcinoma; PDO, patient-derived organoids.

\subsection{Drug Screening Test for PDAC Using Organoids}

The feasibility of a drug screening study using PDOs was first shown in metastatic, heavily pretreated colorectal and gastroesophageal cancer patients recruited in phase I/II clinical trials. They showed PDOS drug screening with 100\% sensitivity, 93\% specificity, $88 \%$ positive predictive value, and $100 \%$ negative predictive value in forecasting response to targeted agents or chemotherapy in patients [16]. Several pilot studies on PDAC drug screening related to clinical data have been vigorously pursued based on this milestone study $[56,62,77]$. The report by Tiriac et al. is currently the largest study of drug screening using PDOs [62]. They performed drug screening of five anticancer drugs for 63 cases of PDOs. The sensitivity to each drug was evaluated in three divisions, and the efficacy in the clinic was shown, although it included a small number of cases. They combined drug screening data from PDOs with genetic data to create original indexes. These indexes indicated that tumor responsiveness to FORFIRINOX was superior in the oxaliplatinsensitive group, but there was no difference in susceptibility to 5-FU and SN-38 (irinotecan). The study also presented the course of treatment in one case of PDAC. The results of the drug screening study using organoids established multiple times in chronological order from this case reflected the tumor profile in actual clinical practice. It demonstrated the usefulness of time-series organoid drug screening. Moreover, Driehuis et al. showed the usefulness of the drug screening test in a limited number of four patients who created PDOs [56]. These two studies involving numerous PDO cell lines and patient follow-ups demonstrated a significant correlation between the PDAC PDO response and the clinical patient's response for the gemcitabine-paclitaxel and FOLFIRINOX treatments, despite the small sample size.

Wolff et al. followed one patient with PDAC for five years, with clinical records, pathology, dynamic evolution of molecular and cellular changes, chemotherapy and targeted therapy with PDOs culture over time, and the response to treatment with immunother- 
apy [57]. Although this only followed one patient, detailed tumor profiles over time demonstrated the usefulness of drug screening with PDOs.

In addition, Frappart et al. also reported a drug screening study for 22 anticancer drugs in patients with PDAC [77]. In the representative cases presented in this study, the screening test result was clarified five days after the initial treatment of FORFIRINOX for metastatic PDAC. Drug screening testing revealed that paclitaxel and gemcitabine were significantly more effective than other therapeutic agents. The tumor diameter increased by $29 \%$ after the initial FORFIRINOX treatment, but there was a significant therapeutic effect by changing to gemcitabine + paclitaxel treatment in this case.

As described above, PDAC drug screening has not yet been totally successful. This may be related to the lack of effective anticancer drugs and the microenvironmental factors of tumors exhibiting strong fibrosis. In addition, as described in the previous section, a method for determining the therapeutic effect of high-throughput drug screening for PDAC organoids has not been implemented in clinical practice. To implement PDOs drug screening in actual clinical practice, a large number of studies and development of more effective anticancer agents are required in metastatic PDAC cases.

\section{Additional Diagnostic Methods for PDACs}

The amount and quality of tissues extracted using EUS-guided sampling are frequently insufficient for histopathological diagnosis, despite improved puncture techniques and needles. New diagnostic methods in addition to EUS-guided sampling, such as microRNAbased tests [78], confocal laser endomicroscopy [79], and proteomics-based tests [80], have been reported to have potential for future clinical application. A recent development in this field is the use of lipid profiling by probe electrospray ionization mass spectrometry and machine learning, including artificial intelligence for diagnosis. Specifically, probe electrospray ionization mass spectrometry (PESI-MS) can rapidly achieve direct mass spectrometry using a very fine needle to collect a small amount of tissue without pretreatment. It also detects low molecular weight metabolites and lipids, which provide important information for disease detection. The accumulation of spectrum patterns for machine learning may allow rapid diagnosis of tumors or accurate identification of the sample within several minutes. Furthermore, PESI-MS has been reported to be effective for the diagnosis of head and neck squamous cell carcinoma [81], hepatocellular carcinoma [82], breast cancer, and renal cell carcinoma [83]. In several studies with other tumors, PESI-MS can be used for rapid diagnosis in minutes. Using EUS-guided sampling of PDAC for PESI-MS can be a faster diagnostic method than pathological diagnosis which can take days. Additionally, rapid blood-based diagnostic modalities to detect PDAC with high accuracy have been recently reported [84]. By applying more cases to machine learning and utilizing artificial intelligence, there is a possibility that subtypes of PDAC can be detected and used to improve personalized medicine in the future.

\section{Conclusions}

Personalized medicine for PDAC is still in development. Consequently, PDAC has a low sensitivity to anticancer drugs and is typically intractable. However, advances in personalized cancer care for PDAC will allow improved chemotherapy selection and more effective patient selection, as well as facilitate the identification of patients in whom chemotherapy may be ineffective, thus avoiding unnecessary treatment. It is expected that the combined use of gene profiling based on genetic testing and pharmaceutical profiling using HTS and PDOs will revolutionize PDAC treatment.

We recommend the use of FNB needles to collect DNA for genomic testing because of its ability to extract more tissue. Clinical studies on the diameter of needles, number of needle passes, and processing techniques are needed. Additionally, EUS-guided sampling is expected to help identify changes in tumor sensitivity over time and identify patientspecific response to chemotherapy. EUS-guided sampling has few complications and allows 
for repeat tissue sampling. Therefore, it is expected that regular PDO preparation using EUS-guided sampling during the course of treatment will improve treatment accuracy.

Author Contributions: Conceptualization, E.I.; methodology, E.I.; software, E.I.; validation, E.I.; formal analysis, E.I.; investigation, E.I.; resources, E.I.; data curation, E.I.; writing-original draft preparation, E.I.; writing—review and editing, S.F., M.H., S.K., T.S., Y.T., H.T., Y.M., A.K., M.N., H.H. and T.K.; visualization, E.I.; supervision, T.K.; project administration, E.I.; funding acquisition, E.I. All authors have read and agreed to the published version of the manuscript.

Funding: This work was supported by JSPS KAKENHI Grant Number 19K07739.

Institutional Review Board Statement: Not applicable.

Informed Consent Statement: Not applicable.

Conflicts of Interest: The authors declare no conflict of interest.

\section{References}

1. Bray, F.; Ferlay, J.; Soerjomataram, I.; Siegel, R.L.; Torre, L.A.; Jemal, A. Global cancer statistics 2018: GLOBOCAN estimates of incidence and mortality worldwide for 36 cancers in 185 countries. CA Cancer J. Clin. 2018, 68, 394-424. [CrossRef] [PubMed]

2. Vincent, A.; Herman, J.; Schulick, R.; Hruban, R.H.; Goggins, M. Pancreatic cancer. Lancet 2011, 378, 607-620. [CrossRef]

3. Siegel, R.L.; Miller, K.D.; Fuchs, H.E.; Jemal, A. Cancer Statistics, 2021. CA Cancer J. Clin. 2021, 71, 7-33. [CrossRef] [PubMed]

4. Pishvaian, M.J.; Blais, E.M.; Brody, J.R.; Lyons, E.; DeArbeloa, P.; Hendifar, A.; Mikhail, S.; Chung, V.; Sahai, V.; Sohal, D.P.S.; et al. Overall survival in patients with pancreatic cancer receiving matched therapies following molecular profiling: A retrospective analysis of the Know Your Tumor registry trial. Lancet Oncol. 2020, 21, 508-518. [CrossRef]

5. Li, D.F.; Wang, J.Y.; Yang, M.F.; Xiong, F.; Zhang, D.G.; Xu, Z.L.; Luo, M.H.; Jing, Z.D.; Wang, K.X.; Wang, L.S.; et al. Factors associated with diagnostic accuracy, technical success and adverse events of endoscopic ultrasound-guided fine-needle biopsy: A systematic review and meta-analysis. J. Gastroenterol. Hepatol. 2020, 35, 1264-1276. [CrossRef] [PubMed]

6. Kandel, P.; Nassar, A.; Gomez, V.; Raimondo, M.; Woodward, T.A.; Crook, J.E.; Fares, N.S.; Wallace, M.B. Comparison of endoscopic ultrasound-guided fine-needle biopsy versus fine-needle aspiration for genomic profiling and DNA yield in pancreatic cancer: A randomized crossover trial. Endoscopy 2020. online ahead of print. [CrossRef]

7. Berry, W.; Lundy, J.; Croagh, D.; Jenkins, B.J. Reviewing the utility of EUS FNA to advance precision medicine in pancreatic cancer. Cancers 2018, 10, 35. [CrossRef]

8. Tiriac, H.; Bucobo, J.C.; Tzimas, D.; Grewel, S.; Lacomb, J.F.; Rowehl, L.M.; Nagula, S.; Wu, M.; Kim, J.; Sasson, A.; et al. Successful creation of pancreatic cancer organoids by means of EUS-guided fine-needle biopsy sampling for personalized cancer treatment. Gastrointest. Endosc. 2018, 87, 1474-1480. [CrossRef] [PubMed]

9. Cloyd, J.M.; Heh, V.; Pawlik, T.M.; Ejaz, A.; Dillhoff, M.; Tsung, A.; Williams, T.; Abushahin, L.; Bridges, J.F.P.; Santry, H. Neoadjuvant therapy for resectable and borderline resectable pancreatic cancer: A meta-analysis of randomized controlled trials. J. Clin. Med. 2020, 9, 1129. [CrossRef] [PubMed]

10. Larson, B.K.; Tuli, R.; Jamil, L.H.; Lo, S.K.; Deng, N.; Hendifar, A.E. Utility of endoscopic ultrasound-guided biopsy for next-generation sequencing of pancreatic exocrine malignancies. Pancreas 2018, 47, 990-995. [CrossRef]

11. Bournet, B.; Pointreau, A.; Souque, A.; Oumouhou, N.; Muscari, F.; Lepage, B.; Senesse, P.; Barthet, M.; Lesavre, N.; Hammel, P.; et al. Gene expression signature of advanced pancreatic ductal adenocarcinoma using low density array on endoscopic ultrasound-guided fine needle aspiration samples. Pancreatology 2012, 12, 27-34. [CrossRef] [PubMed]

12. Kapałczyńska, M.; Kolenda, T.; Przybyła, W.; Zajączkowska, M.; Teresiak, A.; Filas, V.; Ibbs, M.; Bliźniak, R.; Łuczewski, Ł.; Lamperska, K. 2D and 3D cell cultures-A comparison of different. Arch. Med. Sci. 2016, 14, 910-919.

13. Hyman, D.M.; Taylor, B.S.; Baselga, J. Implementing genome-driven oncology. Cell 2017, 168, 584-599. [CrossRef] [PubMed]

14. Schütte, M.; Risch, T.; Abdavi-Azar, N.; Boehnke, K.; Schumacher, D.; Keil, M.; Yildiriman, R.; Jandrasits, C.; Borodina, T.; Amstislavskiy, V.; et al. Molecular dissection of colorectal cancer in pre-clinical models identifies biomarkers predicting sensitivity to EGFR inhibitors. Nat. Commun. 2017, 8, 14262. [CrossRef]

15. Phan, N.; Hong, J.J.; Tofig, B.; Mapua, M.; Elashoff, D.; Moatamed, N.A.; Huang, J.; Memarzadeh, S.; Damoiseaux, R.; Soragni, A. A simple high-throughput approach identifies actionable drug sensitivities in patient-derived tumor organoids. Commun. Biol. 2019, 2, 1-11. [CrossRef]

16. Vlachogiannis, G.; Hedayat, S.; Vatsiou, A.; Jamin, Y.; Fernández-Mateos, J.; Khan, K.; Lampis, A.; Eason, K.; Huntingford, I.; Burke, R.; et al. Patient-derived organoids model treatment response of metastatic gastrointestinal cancers. Science 2018, 359, 920-926. [CrossRef]

17. Biankin, A.V.; Piantadosi, S.; Hollingsworth, S.J. Patient-centric trials for therapeutic development in precision oncology. Nature 2015, 526, 361-370. [CrossRef]

18. Renfro, L.A.; Sargent, D.J. Statistical controversies in clinical research: Basket trials, umbrella trials, and other master protocols: A review and examples. Ann. Oncol. 2017, 28, 34-43. [CrossRef] 
19. Redig, A.J.; Jänne, P.A. Basket trials and the evolution of clinical trial design in an era of genomic medicine. J. Clin. Oncol. 2015, 33, 975-977. [CrossRef] [PubMed]

20. Cunanan, K.M.; Gonen, M.; Shen, R.; Hyman, D.M.; Riely, G.J.; Begg, C.B.; Iasonos, A. Basket trials in oncology: A trade-off between complexity and efficiency. J. Clin. Oncol. 2017, 35, 271-273. [CrossRef] [PubMed]

21. Kopetz, S.; Grothey, A.; Yaeger, R.; Van Cutsem, E.; Desai, J.; Yoshino, T.; Wasan, H.; Ciardiello, F.; Loupakis, F.; Hong, Y.S.; et al. Encorafenib, Binimetinib, and Cetuximab in BRAF V600E-Mutated Colorectal Cancer. N. Engl. J. Med. 2019, 381, $1632-1643$. [CrossRef]

22. Redman, M.W.; Papadimitrakopoulou, V.; Minichiello, K.; Gandara, D.R.; Hirsch, F.R.; Mack, P.C.; Schwartz, L.H.; Vokes, E.E.; Ramalingam, S.S.; Leighl, N.B.; et al. Lung-MAP (SWOG S1400): Design, implementation, and lessons learned from a biomarker-driven master protocol (BDMP) for previously-treated squamous lung cancer (sqNSCLC). J. Clin. Oncol. 2020, $38,9576$. [CrossRef]

23. van Cutsem, E.; Huijberts, S.; Grothey, A.; Yaeger, R.; Cuyle, P.; Elez, E. Therapy for patients with BRAF V600E—Mutant metastatic colorectal cancer: Safety lead-in results from the phase III BEACON colorectal cancer study. J. Clin. Oncol. 2019, 37, 22-24. [CrossRef]

24. Kohno, T. Implementation of "clinical sequencing" in cancer genome medicine in Japan. Cancer Sci. 2018, 109, 507-512. [CrossRef]

25. Kris, M.G.; Johnson, B.E.; Berry, L.D.; Kwiatkowski, D.J.; Iafrate, A.J.; Wistuba, I.I.; Varella-Garcia, M.; Franklin, W.A.; Aronson, S.L.; Su, P.F.; et al. Using multiplexed assays of oncogenic drivers in lung cancers to select targeted drugs. JAMA J. Am. Med. Assoc. 2014, 311, 1998-2006. [CrossRef]

26. Maemondo, M.; Inoue, A.; Kobayashi, K.; Sugawara, S.; Oizumi, S.; Isobe, H.; Gemma, A.; Harada, M.; Yoshizawa, H.; Kinoshita, I.; et al. Gefitinib or chemotherapy for non-small-cell lung cancer with mutated EGFR. N. Engl. J. Med. 2010, 362, 2380-2388. [CrossRef]

27. Shaw, A.T.; Kim, D.-W.; Nakagawa, K.; Seto, T.; Crinó, L.; Ahn, M.-J.; De Pas, T.; Besse, B.; Solomon, B.J.; Blackhall, F.; et al. Crizotinib versus chemotherapy in advanced ALK-positive lung cancer. N. Engl. J. Med. 2013, 368, 2385-2394. [CrossRef]

28. Shaw, A.T.; Ou, S.-H.I.; Bang, Y.-J.; Camidge, D.R.; Solomon, B.J.; Salgia, R.; Riely, G.J.; Varella-Garcia, M.; Shapiro, G.I.; Costa, D.B.; et al. Crizotinib in ROS1-Rearranged Non-Small-Cell Lung Cancer. N. Engl. J. Med. 2014, 371, 1963-1971. [CrossRef]

29. Drilon, A.; Laetsch, T.W.; Kummar, S.; DuBois, S.G.; Lassen, U.N.; Demetri, G.D.; Nathenson, M.; Doebele, R.C.; Farago, A.F.; Pappo, A.S.; et al. Efficacy of larotrectinib in TRK fusion-positive cancers in adults and children. N. Engl. J. Med. 2018, 378, 731-739. [CrossRef]

30. Zehir, A.; Benayed, R.; Shah, R.H.; Syed, A.; Middha, S.; Kim, H.R.; Srinivasan, P.; Gao, J.; Chakravarty, D.; Devlin, S.M.; et al. Mutational landscape of metastatic cancer revealed from prospective clinical sequencing of 10,000 patients. Nat. Med. 2017, 23, 703-713. [CrossRef] [PubMed]

31. Itoi, T.; Sofuni, A.; Itokawa, F.; Irisawa, A.; Khor, C.J.L.; Rerknimitr, R. Current status of diagnostic endoscopic ultrasonography in the evaluation of pancreatic mass lesions. Dig. Endosc. 2011, 23, 17-21. [CrossRef]

32. Vilmann, P.; Hancke, S.; Henriksen, F.W.; Jacobsen, G.K. Endosonographically-guided fine needle aspiration biopsy of malignant lesions in the upper gastrointestinal tract. Endoscopy 1993, 25, 523-527. [CrossRef]

33. Möller, K.; Papanikolaou, I.S.; Toermer, T.; Delicha, E.M.; Sarbia, M.; Schenck, U.; Koch, M.; Al-Abadi, H.; Meining, A.; Schmidt, H.; et al. EUS-guided FNA of solid pancreatic masses: High yield of 2 passes with combined histologic-cytologic analysis. Gastrointest. Endosc. 2009, 70, 60-69. [CrossRef]

34. Iwashita, T.; Yasuda, I.; Mukai, T.; Doi, S.; Nakashima, M.; Uemura, S.; Mabuchi, M.; Shimizu, M.; Hatano, Y.; Hara, A.; et al. Macroscopic on-site quality evaluation of biopsy specimens to improve the diagnostic accuracy during EUS-guided FNA using a 19-gauge needle for solid lesions: A single-center prospective pilot study (MOSE study). Gastrointest. Endosc. 2015, 81, 177-185. [CrossRef] [PubMed]

35. Eloubeidi, M.A.; Jhala, D.; Chhieng, D.C.; Chen, V.K.; Eltoum, I.; Vickers, S.; Wilcox, C.M.; Jhala, N. Yield of endoscopic ultrasoundguided fine-needle aspiration biopsy in patients with suspected pancreatic carcinoma: Emphasis on atypical, suspicious, and false-negative aspirates. Cancer 2003, 99, 285-292. [CrossRef]

36. Norton, I.D.; Petersen, B.T.; Bosco, J.; Nelson, D.B.; Meier, P.B.; Baron, T.H.; Lange, S.M.; Gostout, C.J.; Loeb, D.S.; Levy, M.J.; et al. A randomized trial of endoscopic biliary sphincterotomy using pure-cut versus combined cut and coagulation waveforms. Clin. Gastroenterol. Hepatol. 2005, 3, 1029-1033. [CrossRef]

37. Bang, J.Y.; Hawes, R.; Varadarajulu, S. A meta-analysis comparing ProCore and standard fine-needle aspiration needles for endoscopic ultrasound-guided tissue acquisition. Endoscopy 2016, 48, 339-349. [CrossRef] [PubMed]

38. Ishigaki, K.; Nakai, Y.; Oyama, H.; Kanai, S.; Suzuki, T.; Nakamura, T.; Sato, T.; Hakuta, R.; Saito, K.; Saito, T.; et al. Endoscopic ultrasound-guided tissue acquisition by 22-gauge franseen and standard needles for solid pancreatic lesions. Gut Liver 2020, 14, 817-825. [CrossRef]

39. Oppong, K.W.; Bekkali, N.L.H.; Leeds, J.S.; Johnson, S.J.; Nayar, M.K.; Darné, A.; Egan, M.; Bassett, P.; Haugk, B. Fork-tip needle biopsy versus fine-needle aspiration in endoscopic ultrasound-guided sampling of solid pancreatic masses: A randomized crossover study. Endoscopy 2020, 52, 454-461. [CrossRef]

40. Hayashi, H.; Tanishima, S.; Fujii, K.; Mori, R.; Okamura, Y.; Yanagita, E.; Matsuoka, R.; Amano, T.; Kinoshita, I.; Komatsu, Y.; et al. Genomic testing for pancreatic cancer in clinical practice as real-world evidence. Pancreatology 2018, 18, 647-654. [CrossRef] 
41. Fujita, H.; Ohuchida, K.; Mizumoto, K.; Itaba, S.; Ito, T.; Nakata, K.; Yu, J.; Kayashima, T.; Souzaki, R.; Tajiri, T.; et al. Gene expression levels as predictive markers of outcome in pancreatic cancer after gemcitabine-based adjuvant chemotherapy. Neoplasia 2010, 12, 807-817. [CrossRef]

42. Ashida, R.; Nakata, B.; Shigekawa, M.; Mizuno, N.; Sawaki, A.; Hirakawa, K.; Arakawa, T.; Yamao, K. Gemcitabine sensitivityrelated mRNA expression in endoscopic ultrasound-guided fine-needle aspiration biopsy of unresectable pancreatic cancer. $J$. Exp. Clin. Cancer Res. 2009, 28, 1-7. [CrossRef]

43. Bang, J.Y.; Magee, S.H.; Ramesh, J.; Trevino, J.M.; Varadarajulu, S. Randomized trial comparing fanning with standard technique for endoscopic ultrasound-guided fine-needle aspiration of solid pancreatic mass lesions. Endoscopy 2013, 45, 445-450. [CrossRef]

44. Bang, J.Y.; Hebert-Magee, S.; Navaneethan, U.; Hasan, M.K.; Hawes, R.; Varadarajulu, S. EUS-guided fine needle biopsy of pancreatic masses can yield true histology: Results of a randomised trial. Gut 2017, 67, 2081-2084. [CrossRef]

45. Archibugi, L.; Ruta, V.; Panzeri, V.; Redegalli, M.; Testoni, S.G.G.; Petrone, M.C.; Rossi, G.; Falconi, M.; Reni, M.; Doglioni, C.; et al. RNA extraction from endoscopic ultrasound-acquired tissue of pancreatic cancer is feasible and allows investigation of molecular features. Cells 2020, 9, 2561. [CrossRef] [PubMed]

46. Elhanafi, S.; Mahmud, N.; Vergara, N.; Kochman, M.L.; Das, K.K.; Ginsberg, G.G.; Rajala, M.; Chandrasekhara, V. Comparison of endoscopic ultrasound tissue acquisition methods for genomic analysis of pancreatic cancer. J. Gastroenterol. Hepatol. 2019, 34, 907-913. [CrossRef]

47. Semaan, A.; Bernard, V.; Lee, J.J.; Wong, J.W.; Huang, J.; Swartzlander, D.B.; Stephens, B.M.; Monberg, M.E.; Weston, B.; Bhutani, M.S.; et al. Defining the comprehensive genomic landscapes of pancreatic ductal adenocarcinoma using real world endoscopic aspiration samples. Clin. Cancer Res. 2020, 27, 1082-1093. [CrossRef]

48. Jones, S.; Zhang, X.; Parsons, D.W.; Lin, J.C.H.; Leary, R.J.; Angenendt, P.; Mankoo, P.; Carter, H.; Kamiyama, H.; Jimeno, A.; et al. Core signaling pathways in human pancreatic cancers revealed by global genomic analyses. Science 2008, 321, 1801-1806. [CrossRef]

49. Waddell, N.; Pajic, M.; Patch, A.M.; Chang, D.K.; Kassahn, K.S.; Bailey, P.; Johns, A.L.; Miller, D.; Nones, K.; Quek, K.; et al. Whole genomes redefine the mutational landscape of pancreatic cancer. Nature 2015, 518, 495-501. [CrossRef]

50. Hayashi, H.; Kohno, T.; Ueno, H.; Hiraoka, N.; Kondo, S.; Saito, M.; Shimada, Y.; Ichikawa, H.; Kato, M.; Shibata, T.; et al. Utility of assessing the number of mutated KRAS, CDKN2A, TP53, and SMAD4 genes using a targeted deep sequencing assay as a prognostic biomarker for pancreatic cancer. Pancreas 2017, 46, 335-340. [CrossRef]

51. Lowery, M.A.; Jordan, E.J.; Basturk, O.; Ptashkin, R.N.; Zehir, A.; Berger, M.F.; Leach, T.; Herbst, B.; Askan, G.; Maynard, H.; et al. Real-time genomic profiling of pancreatic ductal adenocarcinoma: Potential actionability and correlation with clinical phenotype. Clin. Cancer Res. 2017, 23, 6094-6100. [CrossRef]

52. Golan, T.; Hammel, P.; Reni, M.; Van Cutsem, E.; Macarulla, T.; Hall, M.J.; Park, J.-O.; Hochhauser, D.; Arnold, D.; Oh, D.-Y.; et al. Maintenance olaparib for germline BRCA-mutated metastatic pancreatic cancer. N. Engl. J. Med. 2019, 381, 317-327. [CrossRef]

53. Nicolle, R.; Blum, Y.; Marisa, L.; Loncle, C.; Gayet, O.; Moutardier, V.; Turrini, O.; Giovannini, M.; Bian, B.; Bigonnet, M.; et al. Pancreatic adenocarcinoma therapeutic targets revealed by tumor-stroma cross-talk analyses in patient-derived xenografts. Cell Rep. 2017, 21, 2458-2470. [CrossRef] [PubMed]

54. Bailey, P.; Chang, D.K.; Nones, K.; Johns, A.L.; Patch, A.M.; Gingras, M.C.; Miller, D.K.; Christ, A.N.; Bruxner, T.J.C.; Quinn, M.C.; et al. Genomic analyses identify molecular subtypes of pancreatic cancer. Nature 2016, 531, 47-52. [CrossRef] [PubMed]

55. Witkiewicz, A.K.; Balaji, U.; Eslinger, C.; McMillan, E.; Conway, W.; Posner, B.; Mills, G.B.; O’Reilly, E.M.; Knudsen, E.S. Integrated patient-derived models delineate individualized therapeutic vulnerabilities of pancreatic cancer. Cell Rep. 2016, 16, $2017-2031$. [CrossRef]

56. Driehuis, E.; Van Hoeck, A.; Moore, K.; Kolders, S.; Francies, H.E.; Gulersonmez, M.C.; Stigter, E.C.A.; Burgering, B.; Geurts, V.; Gracanin, A.; et al. Pancreatic cancer organoids recapitulate disease and allow personalized drug screening. Proc. Natl. Acad. Sci. USA 2019, 116, 26580-26590. [CrossRef] [PubMed]

57. Wolff, R.A.; Wang-Gillam, A.; Alvarez, H.; Tiriac, H.; Engle, D.; Hou, S.; Groff, A.F.; Lucas, A.S.; Bernard, V.; Allenson, K.; et al. Dynamic changes during the treatment of pancreatic cancer. Oncotarget 2018, 9, 14764-14790. [CrossRef] [PubMed]

58. Huang, L.; Holtzinger, A.; Jagan, I.; Begora, M.; Lohse, I.; Ngai, N.; Nostro, C.; Wang, R.; Muthuswamy, L.B.; Crawford, H.C.; et al. Ductal pancreatic cancer modeling and drug screening using human pluripotent stem cell- and patient-derived tumor organoids. Nat. Med. 2015, 21, 1364-1371. [CrossRef] [PubMed]

59. Ricci-Vitiani, L.; Lombardi, D.G.; Pilozzi, E.; Biffoni, M.; Todaro, M.; Peschle, C.; De Maria, R. Identification and expansion of human colon-cancer-initiating cells. Nature 2007, 445, 111-115. [CrossRef] [PubMed]

60. Nakamoto, N.; Sasaki, N.; Aoki, R.; Miyamoto, K.; Suda, W.; Teratani, T.; Suzuki, T.; Koda, Y.; Chu, P.S.; Taniki, N.; et al. Gut pathobionts underlie intestinal barrier dysfunction and liver $\mathrm{T}$ helper 17 cell immune response in primary sclerosing cholangitis. Nat. Microbiol. 2019, 4, 492-503. [CrossRef] [PubMed]

61. Seino, T.; Kawasaki, S.; Shimokawa, M.; Tamagawa, H.; Toshimitsu, K.; Fujii, M.; Ohta, Y.; Matano, M.; Nanki, K.; Kawasaki, K.; et al. Human pancreatic tumor organoids reveal loss of stem cell niche factor dependence during disease progression. Cell Stem Cell 2018, 22, 454-467.e6. [CrossRef] [PubMed]

62. Tiriac, H.; Belleau, P.; Engle, D.D.; Plenker, D.; Deschênes, A.; Somerville, T.D.D.; Froeling, F.E.M.; Burkhart, R.A.; Denroche, R.E.; Jang, G.H.; et al. Organoid profiling identifies common responders to chemotherapy in pancreatic cancer. Cancer Discov. 2018, 8 , 1112-1129. [CrossRef] [PubMed] 
63. Tuveson, D.; Clevers, H. Cancer modeling meets human organoid technology. Science 2019, 364, 952-955. [CrossRef] [PubMed]

64. Nanki, K.; Fujii, M.; Shimokawa, M.; Matano, M.; Nishikori, S.; Date, S.; Takano, A.; Toshimitsu, K.; Ohta, Y.; Takahashi, S.; et al. Somatic inflammatory gene mutations in human ulcerative colitis epithelium. Nature 2020, 577, 254-259. [CrossRef] [PubMed]

65. Nanki, K.; Toshimitsu, K.; Takano, A.; Fujii, M.; Shimokawa, M.; Ohta, Y.; Matano, M.; Seino, T.; Nishikori, S.; Ishikawa, K.; et al. Divergent routes toward wnt and R-spondin niche independency during human gastric carcinogenesis. Cell 2018, 174, 856-869.e17. [CrossRef] [PubMed]

66. Sbeit, W.; Kadah, A.; Mari, A.; Mahamid, M.; Khoury, T. A Comprehensive narrative review on the evolving role of endoscopic ultrasound in focal solid liver lesions diagnosis and management. Diagnostics 2020, 10, 688. [CrossRef]

67. Yao, Y.; Xu, X.; Yang, L.; Zhu, J.; Wan, J.; Shen, L.; Xia, F.; Fu, G.; Deng, Y.; Pan, M.; et al. Patient-derived organoids predict chemoradiation responses of locally advanced rectal cancer. Cell Stem Cell 2020, 26, 17-26.e6. [CrossRef]

68. Li, D.; Xie, K.; Wolff, R.; Abbruzzese, J.L. Pancreatic cancer. Lancet 2004, 363, 1049-1057. [CrossRef]

69. Bang, J.Y.; Hebert-Magee, S.; Hasan, M.K.; Navaneethan, U.; Hawes, R.; Varadarajulu, S. Endoscopic ultrasonography-guided biopsy using a Franseen needle design: Initial assessment. Dig. Endosc. 2017, 29, 338-346. [CrossRef] [PubMed]

70. Boj, S.F.; Hwang, C.-I.; Baker, L.A.; Chio, I.I.C.; Engle, D.D.; Corbo, V.; Jager, M.; Ponz-Sarvise, M.; Tiriac, H.; Spector, M.S.; et al. Organoid models of human and mouse ductal pancreatic cancer. Cell 2015, 160, 324-338. [CrossRef] [PubMed]

71. Bian, B.; Juiz, N.A.; Gayet, O.; Bigonnet, M.; Brandone, N.; Roques, J.; Cros, J.; Wang, N.; Dusetti, N.; Iovanna, J. Pancreatic cancer organoids for determining sensitivity to bromodomain and extra-terminal inhibitors (BETI). Front. Oncol. 2019, 9, 1-8. [CrossRef] [PubMed]

72. Vilgelm, A.E.; Bergdorf, K.; Wolf, M.; Bharti, V.; Shattuck-Brandt, R.; Blevins, A.; Jones, C.; Phifer, C.; Lee, M.; Lowe, C.; et al. Fine-needle aspiration-based patient-derived cancer organoids. iScience 2020, 23, 101408. [CrossRef]

73. Juiz, N.; Elkaoutari, A.; Bigonnet, M.; Gayet, O.; Roques, J.; Nicolle, R.; Iovanna, J.; Dusetti, N. Basal-like and classical cells coexist in pancreatic cancer revealed by single-cell analysis on biopsy-derived pancreatic cancer organoids from the classical subtype. FASEB J. 2020, 34, 12214-12228. [CrossRef] [PubMed]

74. Lacomb, J.F.; Plenker, D.; Tiriac, H.; Bucobo, J.C.; D’souza, L.S.; Khokhar, A.S.; Patel, H.; Channer, B.; Joseph, D.; Wu, M.; et al. Single-pass vs 2-pass endoscopic ultrasound-guided fine-needle biopsy sample collection for creation of pancreatic adenocarcinoma organoids. Clin. Gastroenterol. Hepatol. 2020. online ahead of print. [CrossRef]

75. Hennig, A.; Wolf, L.; Jahnke, B.; Polster, H.; Seidlitz, T.; Werner, K.; Aust, D.E.; Hampe, J.; Distler, M.; Weitz, J.; et al. CFTR expression analysis for subtyping of human pancreatic cancer organoids. Stem Cells Int. 2019, 2019, 1024614. [CrossRef] [PubMed]

76. Bode, K.J.; Mueller, S.; Schweinlin, M.; Metzger, M.; Brunner, T. A fast and simple fluorometric method to detect cell death in 3D intestinal organoids. Biotechniques 2019, 67, 23-28. [CrossRef]

77. Frappart, P.O.; Hofmann, T.G. Pancreatic ductal adenocarcinoma (Pdac) organoids: The shining light at the end of the tunnel for drug response prediction and personalized medicine. Cancers 2020, 12, 2750. [CrossRef] [PubMed]

78. Brand, R.E.; Adai, A.T.; Centeno, B.A.; Lee, L.S.; Rateb, G.; Vignesh, S.; Menard, C.; Wiechowska-Kozłowska, A.; Bołdys, H.; Hartleb, M.; et al. A microRNA-based test improves endoscopic ultrasound-guided cytologic diagnosis of pancreatic cancer. Clin. Gastroenterol. Hepatol. 2014, 12, 1717-1723. [CrossRef]

79. Ungureanu, B.S.; Pirici, D.; Dima, S.O.; Popescu, I.; Hundorfean, G.; Surlin, V.; Saftoiu, A. Morphometric assessment of confocal laser endomicroscopy for pancreatic ductal adenocarcinoma, an ex-vivo pilot study. Diagnostics 2020, 10, 923. [CrossRef]

80. Underwood, P.W.; Gerber, M.H.; Nguyen, K.; Delitto, D.; Han, S.; Thomas, R.M.; Forsmark, C.E.; Trevino, J.G.; Gooding, W.E.; Hughes, S.J. Protein signatures and tissue diagnosis of pancreatic cancer. J. Am. Coll. Surg. 2020, 230, 26-36.e1. [CrossRef]

81. Ashizawa, K.; Yoshimura, K.; Johno, H.; Inoue, T.; Katoh, R.; Funayama, S.; Sakamoto, K.; Takeda, S.; Masuyama, K.; Matsuoka, T.; et al. Construction of mass spectra database and diagnosis algorithm for head and neck squamous cell carcinoma. Oral Oncol. 2017, 75, 111-119. [CrossRef] [PubMed]

82. Yoshimura, K.; Mandal, M.K.; Hara, M.; Fujii, H.; Chen, L.C.; Tanabe, K.; Hiraoka, K.; Takeda, S. Real-time diagnosis of chemically induced hepatocellular carcinoma using a novel mass spectrometry-based technique. Anal. Biochem. 2013, 441, 32-37. [CrossRef] [PubMed]

83. Mandal, M.K.; Yoshimura, K.; Chen, L.C.; Yu, Z.; Nakazawa, T.; Katoh, R.; Fujii, H.; Takeda, S.; Nonami, H.; Hiraoka, K. Application of probe electrospray ionization mass spectrometry (PESI-MS) to clinical diagnosis: Solvent effect on lipid analysis. $J$. Am. Soc. Mass Spectrom. 2012, 23, 2043-2047. [CrossRef] [PubMed]

84. Chung, W.Y.; Correa, E.; Yoshimura, K.; Chang, M.C.; Dennison, A.; Takeda, S.; Chang, Y.T. Using probe electrospray ionization mass spectrometry and machine learning for detecting pancreatic cancer with high performance. Am. J. Transl. Res. 2020, 12, 171-179. 